\title{
Improvement of Bearing Capacity of Clay Soil Using Fly Ash
}

\author{
Abul Hasnat ${ }^{\mathrm{a}}$, Safkat Tajwar Ahmed ${ }^{\mathrm{b} *}$, Tahmid Mustafa ${ }^{\mathrm{c}}$, Md. Samiullah Chowdhury ${ }^{\mathrm{d}}$, S. M. Prince
}

\begin{abstract}
The principal aim of the study is to improve the engineering properties of the soil sample using fly ash as a binding material. Bangladeshi fly ash was used in this study. Effects of fly ash on physical and mechanical properties of soil (Atterberg limits, moisture-density relationship, and unconfined compressive strength) are evaluated in the presence of $0 \%, 2 \%$, $4 \%, 5 \%, 8 \%, 10 \%, 15 \%, 20 \% \& 25 \%$ fly ash. For understanding the improvement of engineering properties of soil, a parametric analysis is conducted to determine the allowable bearing capacity, settlement and the time required for the consolidation. The allowable bearing capacity is evaluated using several equations for both saturated and unsaturated conditions. It is found that for $5 \%$ fly ash content, the maximum allowable bearing capacity is achieved. The maximum value of allowable bearing capacity is $660.12 \mathrm{kN} / \mathrm{m} 2$ in the unsaturated condition. The increment of maximum allowable bearing capacity is $\mathbf{7 7 . 7 4 \%}$ for $5 \%$ fly ash content. The lowest value of the settlement was $336 \mathrm{~mm}$ (saturated) and $183 \mathrm{~mm}$ (unsaturated) for $25 \%$ fly ash content. Considering normally consolidated soil, it is found that the least time required for consolidation is 3.19 years for $25 \%$ fly ash content.
\end{abstract}

Index Terms - Fly Ash, unconfined compressive strength, Bearing Capacity, Settlement, clay soil.

\section{INTRODUCTION}

Bangladesh has a large lowland and coastal area, covered with soft clay. As subgrade material, most of the soils classify as AASHTO A-4 to A-7-6, which means they are mainly finegrained silt and clay soils. The problem with these soils is that they have undesirable engineering properties (Şenol et al., 2006; Horpibulsuk et al., 2012), such as low bearing capacity, high shrinkage and swell characteristics (Şenol et al., 2003; Prabakar et al., 2004) Structures and roads built on these soils undergo large amount of settlement (Turner, 1997; Tastan et al., 2011). These problematic soils usually have low shear strength (Senol et al., 2002). Therefore, modifications of engineering properties of these soils should be done through a process called soil stabilization (Dermatas and Meng, 2003;

a. Assistant Professor, Civil Engineering, Faculty of Engineering, American International University-Bangladesh, Dhaka, Bangladesh

$b^{*}$. Lecturer, Department of Civil Engineering, Sonargaon University, Dhaka, Bangladesh

c. Lecturer, Department of Civil Engineering, Sonargaon University, Dhaka, Bangladesh

d. QC Engineer, MAX infrastructure Ltd., Chittagong, Bangladesh

e. Third Material Inspector, Frist, Dhaka Elevated Expressway, Dhaka, Bangladesh

*Corresponding Author. Email- safkattajwar@iut-dhaka.edu
Keshawarz and Dutta, 1993) which aggravates the engineering performance of these problematic soils (Savran et al., 1988; Inan and Sezer, 2003). The binders used for the present is fly ash. Haque (2013) stated that Bangladesh has six potential coal fields with fly ash production of 1 million tons per years, and the Barapukuria Coal-fired Thermal Power Plant alone produces $65 \%$ of the total production. So, using the fly ash for soil stabilization would be a great way to minimize the waste and maximize the profit (Chu and Kao, 1993; Kumar and Sharma, 2004; Zha et al., 2008).

\section{EXPERIMENTAL PROGRAM}

The soil sample was collected from $3 \mathrm{~m}$ below (Horpibulsuk et al., 2010) of a paddy field for the present study. Tests that were carried out for the collected soil sample were field moisture content, field density, grain size analysis, specific gravity test, Atterberg limits test, compaction test and unconfined compression test.

Atterberg limits tests were also performed in the presence of $2 \%, 4 \%, 5 \%, 8 \%, 10 \%, 15 \%, 20 \%$ and $25 \%$ (mass/mass) fly ash. Compaction tests and unconfined compression tests were performed in the presence of $0 \%, 2 \%, 4 \%, 5 \%, 8 \%, 10 \%$, $15 \%, 20 \%$ and $25 \%$ fly ash for determining the maximum dry density and unconfined compressive strength. The unconfined compressive test sample was tested at 3, 7, 14, 28 and 90 days.

\section{A. Moisture Content Test}

ASTM D2216-04 Standard Test Method for laboratory determination of moisture content of the soil, rock, and soilaggregate mixtures was followed for the experiments. Average value of moisture content was found $43.1285 \%$. The water content was relatively high as the soil was from a paddy field.

\section{B. Specific Gravity Test}

ASTM D854-00 Standard was followed throughout the experiments. The specific gravity was found to be 2.58 , which falls between the range of clay (1.8 2.6). The specific gravity of soil was relatively high as a higher percentage of organic component was present in the paddy field.

\section{Grain Size Analysis}

ASTM D422-04 Standard test method was followed. The soil was found to be composed of $1.46 \%$ gravel, $46.89 \%$ sand, $51.65 \%$ silt and clay (Fig. 1). Therefore, the major constituents were silt and clay. 


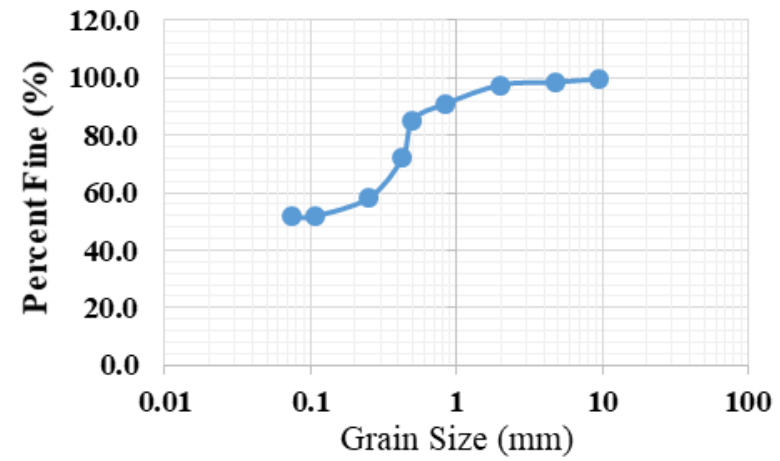

Fig. 1. Grain size distribution of sandy fat clay soil

Ngoma and Chirwa (2011) used clay soil composed of $6.9 \%$ gravel, $33.8 \%$ sand, $59.3 \%$ silt and clay in their research. Sharma et al. (2012) study soil was composed of $0.22 \%$ Gravel, $13.16 \%$ Sand, $74.49 \%$ Silt and $7.45 \%$ Clay.

\section{Atterberg Limits:}

ASTM D4318-04 Standard was followed for the tests. Liquid limits and plastic limits of the sample are shown in Table 1. With the increase of fly ash in the soil, the liquid limit decreased and the plastic limit increased, meaning the soil was losing its consistency for the lower amount of water with the increase of fly ash. content increases and corresponding maximum dry density decreases with the increase fly ash in the soil.

Ngoma and Chirwa (2011) found the MDD and OMC to be $1830,1780,1700$, and $1500 \mathrm{~kg} / \mathrm{m} 3$ and $15 \%, 16 \%, 18 \%$, and $19 \%$, for $0 \%, 10 \%, 20 \%$ and $30 \%$ fly ash content respectively. Sharma et al. (2012) showed that OMC (17.82\%, 18.65\%, $19.42 \%, 17.87 \%$ and $20.46 \%$ ) and $\operatorname{MDD}(1.77,1.87,1.92$, 2.02 and $2.04 \mathrm{~g} / \mathrm{cm} 3$ ) increase with increase in fly ash content $(0 \%, 10 \%, 15 \%, 20 \%$ and $25 \%)$.

\section{F. Unconfined Compression Test}

ASTM D2166-04 Standard test method was followed for the experiments. The mold used for the test was $38.2 \mathrm{~mm}$ (1.50394 in.) in diameter and $78.2 \mathrm{~mm}$ (3.07874 in.) in height. From Table 2, we see that the strength of soil is also increasing, with the curing period, for the increase in fly ash content.

Ngoma and Chirwa (2011) found the compressive strength to be $256.8,337.82,490$ and $375 \mathrm{kN} / \mathrm{m} 2$ for the soil of $0 \%$, $10 \%, 20 \%$ and $30 \%$ fly ash content. Shah et al. (2003), for fuel oil contaminated soil, found that compressive strength is is $61.78,68.65$ and $76.49 \mathrm{KPa}$ for $5 \%, 10 \%$, and $20 \%$ fly ash, respectively for 7 days curing. Sharma et al. (2012) found the compressive strength of soil to be $24.73,34.73,38.83,63.38$ and $45.11 \mathrm{KPa}$ for $0 \%, 10 \%, 15 \%, 20 \%$ and $25 \%$ fly ash

TABLE I

ATTERBERG LIMITS, COMPRESSIBILITY INDEX AND VOID RATIO OF SOIL-FLy ASH MIX

\begin{tabular}{|c|c|c|c|c|c|c|}
\hline Sample No & $\begin{array}{l}\% \text { of } \\
\text { Fly ash }\end{array}$ & $\begin{array}{l}\text { Liquid Limit } \\
\text { (LL) }\end{array}$ & $\begin{array}{l}\text { Plastic Limit } \\
\text { (PL) }\end{array}$ & $\begin{array}{l}\text { Plasticity } \\
\text { Index } \\
\text { (PI) }\end{array}$ & $\begin{array}{l}\text { Compressibility Index } \\
\qquad\left(\boldsymbol{C}_{\boldsymbol{c})}\right.\end{array}$ & $\begin{array}{l}\text { Void } \\
\text { ratio } \\
\left(\boldsymbol{e}_{o}\right)\end{array}$ \\
\hline A. 0.2 & 2 & 54.43 & 29.98 & 24.45 & 0.332 & 0.710 \\
\hline A.O. 4 & 4 & 54.29 & 30.61 & 23.57 & 0.331 & 0.711 \\
\hline A. 0.5 & 5 & 54.25 & 30.67 & 23.58 & 0.330 & 0.732 \\
\hline A. 0.10 & 10 & 53.82 & 32.07 & 21.75 & 0.327 & 0.787 \\
\hline A. 0.15 & 15 & 53.36 & 34.22 & 19.14 & 0.324 & 0.805 \\
\hline A. 0.20 & 20 & 53.06 & 35.65 & 17.41 & 0.322 & 0.810 \\
\hline A. 0.25 & 25 & 52.71 & 37.21 & 15.50 & 0.319 & 0.865 \\
\hline
\end{tabular}

It was observed that liquid limit was decreasing with increasing of fly ash content. For fly ash contents of $0 \%, 10 \%$, $20 \%$ and $30 \%$, liquid limit were $54 \%, 51 \%, 49 \%$, and $47 \%$, respectively. On the other hand, plastic limit $(20 \%, 22 \%, 23 \%$ and $26 \%$ ) increased with increment of fly ash content $(0 \%$, 10\%, 20\% and 30\%) (Ngoma and Chirwa, 2011). Sharma et al. (2012) showed that liquid limit $(34.79 \%, 34.48 \%, 33.83 \%$, $33.21 \%$ and $32.85 \%)$ decrease and plastic limit $(20 \%, 24 \%$, $20.79 \%, 21.28 \%, 21.54 \%$ and $22.09 \%$ ) increase with increase of fly ash content $(0 \%, 10 \%, 15 \%, 20 \%$ and $25 \%)$ in the soil.

\section{E. Compaction Test}

ASTM D1557-04 Standard Test Methods for laboratory compaction characteristics of soil using modified effort $(56,000 \mathrm{ft}-\mathrm{lbs} / \mathrm{ft} 3(2,700 \mathrm{KN}-\mathrm{m} / \mathrm{m} 3))$ was followed. Results are shown in Table 2. We see that the optimum moisture content, respectively, for 90 day curing.

\section{G. Attributes Calculated from Empirical Equations}

For disturbed clay sample or remolding, results are shown in Table 1.

The moisture content of the soil is so high $(43.13 \%)$ that, maximum soil particles are silt and clay $(51.65 \%)$. With the increase of fly ash in the soil, the liquid limit decreases and the plastic limit increases.

The optimum moisture content increases and corresponding maximum dry density decreases with the increase of fly ash in the soil. The strength of soil is increasing, with the curing period, for the increase in fly ash content. 
TABLE II

RESULTS OF COMPACTION TEST AND UNCONFINED COMPRESSION TEST

\begin{tabular}{|c|c|c|c|c|c|c|}
\hline $\begin{array}{c}\text { Sample } \\
\text { type }\end{array}$ & $\begin{array}{c}\% \\
\text { of } \\
\text { Fly } \\
\text { ash }\end{array}$ & $\begin{array}{l}\text { Sampl } \\
\text { e No }\end{array}$ & $\begin{array}{c}\text { Max. } \\
\text { Dry } \\
\text { density } \\
(\mathrm{Kg} / \mathrm{m} 3)\end{array}$ & $\begin{array}{c}\text { Unconfine } \\
\text { d } \\
\text { Compress } \\
\text { ive } \\
\text { Strength } \\
(\mathrm{KN} / \mathrm{m} 2)\end{array}$ & $\begin{array}{c}\text { Optimum } \\
\text { Moisture } \\
\text { Content } \\
(\%)\end{array}$ & $\begin{array}{c}\text { Curing } \\
\text { time } \\
\text { (Days) }\end{array}$ \\
\hline \multirow{5}{*}{$\begin{array}{c}\text { Normal } \\
\text { soil }\end{array}$} & \multirow[t]{5}{*}{$\mathrm{N} /$} & U.S.0. & 1615 & 263.95 & 20.30 & 3 \\
\hline & & U.S.0. & 1615 & 270.99 & 20.30 & 7 \\
\hline & & U.S.0. & 1615 & 277.64 & 20.30 & 14 \\
\hline & & U.S.0. & 1615 & 289.07 & 20.30 & 28 \\
\hline & & U.S.0. & 1615 & 296.70 & 20.30 & 90 \\
\hline \multirow{40}{*}{$\begin{array}{c}\text { Fly ash } \\
\text { mixed } \\
\text { soil }\end{array}$} & \multirow[t]{5}{*}{2} & U.O. 2 & 1591 & 272.98 & 20.52 & 3 \\
\hline & & U.O.2 & 1591 & 297.93 & 20.52 & 7 \\
\hline & & U.O.2 & 1591 & 331.80 & 20.52 & 14 \\
\hline & & U.O. 2 & 1591 & 345.63 & 20.52 & 28 \\
\hline & & U.O.2 & 1591 & 379.61 & 20.52 & 90 \\
\hline & \multirow[t]{5}{*}{4} & U.O.4 & 1576 & 286.55 & 20.77 & 3 \\
\hline & & U.O.4 & 1576 & 318.85 & 20.77 & 7 \\
\hline & & U.O.4 & 1576 & 354.95 & 20.77 & 14 \\
\hline & & U.O.4 & 1576 & 393.67 & 20.77 & 28 \\
\hline & & U.O.4 & 1576 & 442.79 & 20.77 & 90 \\
\hline & \multirow[t]{5}{*}{5} & U.0.5 & 1564 & 299.65 & 20.85 & 3 \\
\hline & & U.O.5 & 1564 & 349.15 & 20.85 & 7 \\
\hline & & U.0.5 & 1564 & 395.40 & 20.85 & 14 \\
\hline & & U.0.5 & 1564 & 430.96 & 20.85 & 28 \\
\hline & & U.0.5 & 1564 & 474.53 & 20.85 & 90 \\
\hline & \multirow[t]{5}{*}{8} & U.O. 8 & 1555 & 291.59 & 21.25 & 3 \\
\hline & & U.O.8 & 1555 & 337.80 & 21.25 & 7 \\
\hline & & U.O.8 & 1555 & 383.32 & 21.25 & 14 \\
\hline & & U.O.8 & 1555 & 419.21 & 21.25 & 28 \\
\hline & & U.O.8 & 1555 & 462.80 & 21.25 & 90 \\
\hline & \multirow[t]{5}{*}{10} & U.O.1 & 1543 & 277.91 & 21.40 & 3 \\
\hline & & U.O.1 & 1543 & 320.90 & 21.40 & 7 \\
\hline & & U.O.1 & 1543 & 361.34 & 21.40 & 14 \\
\hline & & U.O.1 & 1543 & 403.52 & 21.40 & 28 \\
\hline & & U.O.1 & 1543 & 451.44 & 21.40 & 90 \\
\hline & \multirow[t]{5}{*}{15} & U.O.1 & 1523 & 268.19 & 22.56 & 3 \\
\hline & & U.O.1 & 1523 & 301.80 & 22.56 & 7 \\
\hline & & U.O.1 & 1523 & 345.63 & 22.56 & 14 \\
\hline & & U.O.1 & 1523 & 372.74 & 22.56 & 28 \\
\hline & & U.O.1 & 1523 & 406.11 & 22.56 & 90 \\
\hline & \multirow[t]{5}{*}{20} & U.O.2 & 1504 & 244.30 & 23.05 & 3 \\
\hline & & U.O. 2 & 1504 & 271.49 & 23.05 & 7 \\
\hline & & U.O.2 & 1504 & 308.19 & 23.05 & 14 \\
\hline & & U.O.2 & 1504 & 326.93 & 23.05 & 28 \\
\hline & & U.O.2 & 1504 & 371.02 & 23.05 & 90 \\
\hline & \multirow[t]{5}{*}{25} & U.O.2 & 1510 & 230.50 & 23.74 & 3 \\
\hline & & U.O.2 & 1510 & 256.76 & 23.74 & 7 \\
\hline & & U.O. 2 & 1510 & 276.60 & 23.74 & 14 \\
\hline & & U.O.2 & 1510 & 307.58 & 23.74 & 28 \\
\hline & & U.O. 2 & 1510 & 356.66 & 23.74 & 90 \\
\hline
\end{tabular}

\section{H. Parametric Analysis}

For the improvement of soil, fly ash were used. The percentage of fly ash used for soil stabilization were $2 \%, 4 \%$, $5 \%, 8 \%, 10 \%, 15 \%, 20 \%$ and $25 \%$ with a respect time of 3,7 , 14, 28 and 90 days. Evaluation of the allowable bearing capacity was a major concern for achieving the goal.

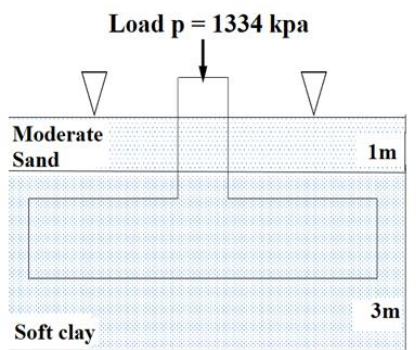

(a)

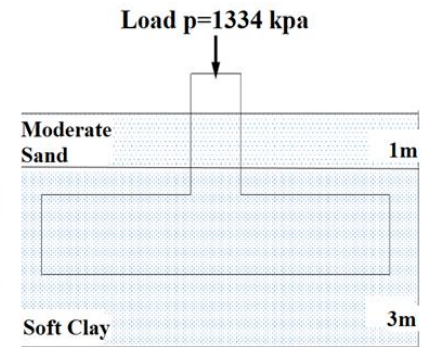

(b)
Fig. 2. Parametric analysis for (a) saturated condition and (b) unsaturated condition

TABLE III

Parametric Analysis Data TABle

\begin{tabular}{cccc}
$\begin{array}{c}\text { Layer } \\
\text { depth } \\
(\mathrm{m})\end{array}$ & $\begin{array}{c}\text { Breath } \\
\text { of square } \\
\text { footing } \\
(\mathrm{m})\end{array}$ & $\begin{array}{c}\text { Depth } \\
\text { of } \\
\text { footing } \\
(\mathrm{m})\end{array}$ & $\begin{array}{c}\text { Soil } \\
\text { type }\end{array}$ \\
\hline 1 & & 2 & $\begin{array}{c}\text { Moderate } \\
\text { sand }\end{array}$ \\
$\mathbf{3}$ & 2.5 & Soft clay \\
\hline
\end{tabular}

\section{RESULTS AND DISCUSSION}

The findings from the parametric analysis are discussed in this section. For different fly ash contents, the allowable bearing capacity, void ratio, settlement, degree of consolidation and time for consolidation are calculated. Moreover, the increment of allowable bearing capacity with time is also measured. These findings are discussed below-

\section{A. Effect of Fly Ash Content on Allowable Bearing Capacity}

The allowable bearing capacity and time graph is plotted for time duration of 90 days for fly ash mixed with normal soil. The analysis was performed by using Terzaghi (1943), Meyerhof (1963), Skempton (1951), Hansen (1970) and Vesic (1973) methods for both saturated and unsaturated conditions.

Fig. 3 shows the allowable bearing capacity and time graph for fly ash-soil mix in saturated condition. From the figure, it can be seen that the maximum allowable bearing capacity was achieved for $5 \%$ fly ash content.

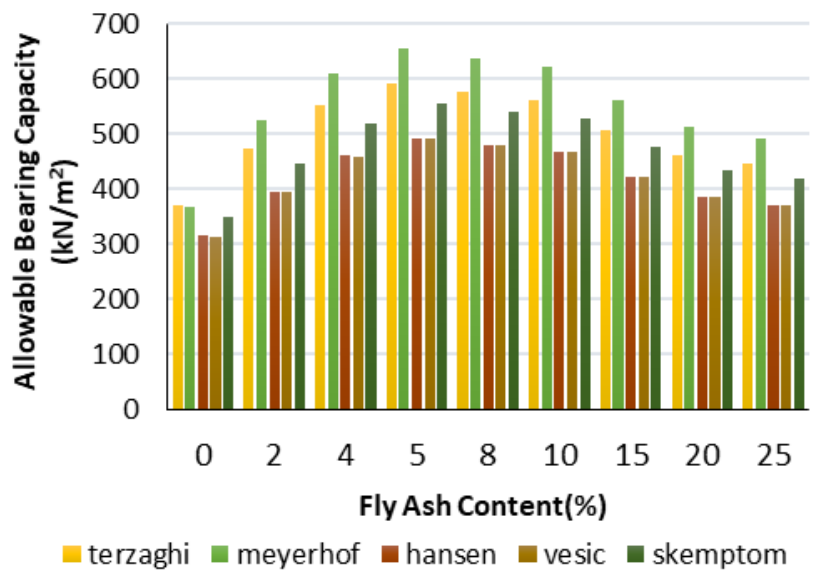

Fig. 3. Comparison of allowable bearing capacity with fly ash content for 90 day time interval (saturated) 
For unsaturated soil, the allowable bearing capacity and time graph for fly ash-soil mix is demonstrated in Fig. 4. The allowable bearing capacity was found to be highest for $5 \%$ fly ash content.

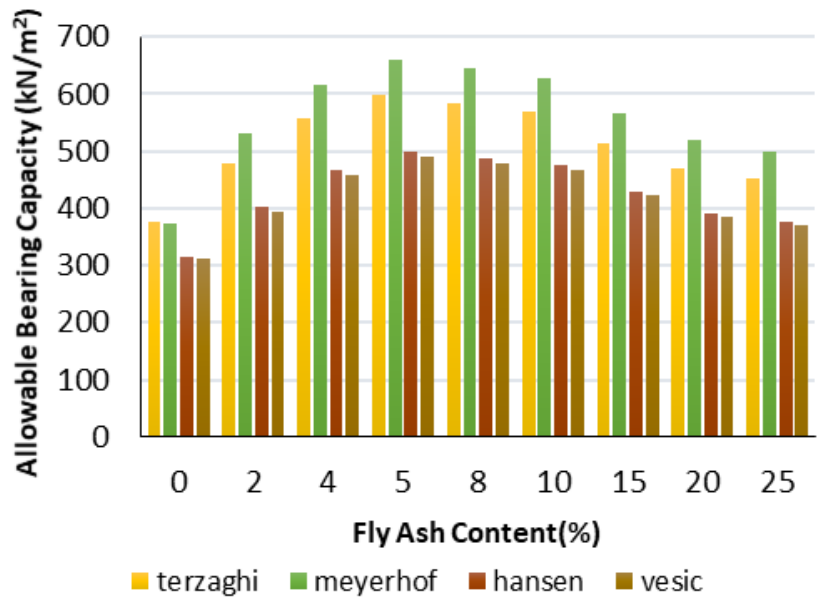

Fig. 4. Comparison of allowable bearing capacity with fly ash content for 90 day time interval (unsaturated)

\section{B. Effect of Time on Allowable Bearing Capacity}

After full analysis, it was found that using Meyerhof's method for fly ash content with the normal soil achieved the maximum allowable bearing capacity.

The relationship of time and allowable bearing capacity for saturated condition of soil and for fly ash mix is shown in Fig. 5 .

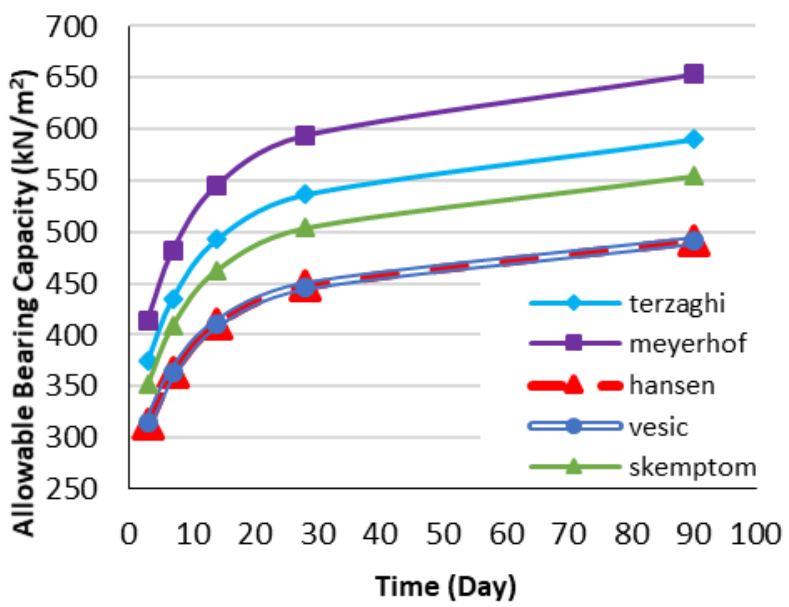

Fig. 5. Effect of allowable bearing capacity with Time for 5\% fly ash (saturated)

This figure represents the allowable bearing capacity calculated by Terzaghi (1943), Meyerhof (1963), Skempton (1951), Hansen (1970) and Vesic (1973) methods for 5\% fly ash content. It is revealed that the maximum value of bearing capacity was found in the 90-day time interval.

In unsaturated condition, the value of bearing capacity increased with the time increment for fly ash and soil mix. Fig. 6 shows that the maximum value of the bearing capacity was found after 90 days for $5 \%$ fly ash content in unsaturated condition.
In unsaturated condition, the value of bearing capacity increased with the time increment for fly ash and soil mix. Fig. 6 shows that the maximum value of the bearing capacity was found after 90 days for $5 \%$ fly ash content in unsaturated condition.

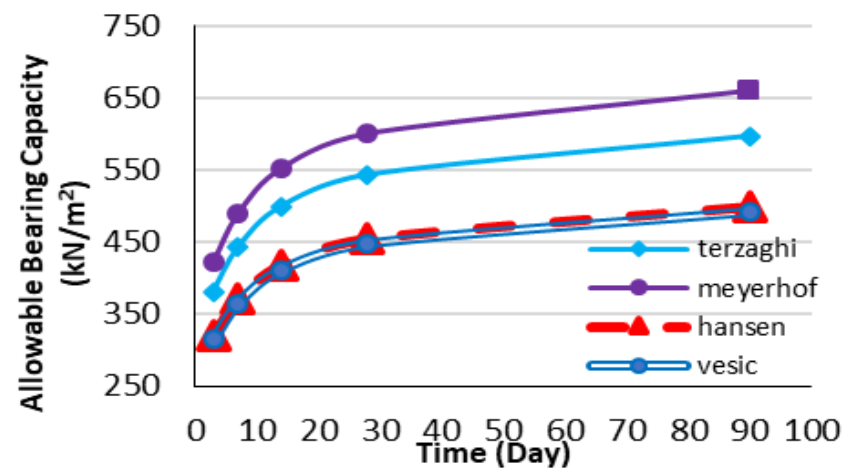

Fig. 6. Effect of allowable bearing capacity with Time for 5\% fly ash (unsaturated)

\section{Combined Effect of Fly Ash Content and Time on Allowable Bearing Capacity}

Soil in a state of fully saturated condition, the maximum allowable bearing capacity was found $653.45 \mathrm{kN} / \mathrm{m} 2$ for 90 day interval. The nearest value at same time interval was $637.30 \mathrm{kN} / \mathrm{m} 2$ for $8 \%$ fly ash content mix (Fig. 7).

For unsaturated condition, from Fig.8, the maximum allowable bearing capacity was found $660.12 \mathrm{kN} / \mathrm{m} 2$ at 90 days interval for $5 \%$ fly ash mix, while the nearest value was $643.97 \mathrm{kN} / \mathrm{m} 2$ for $8 \%$ fly ash content. Similar to the saturated condition, Meyerhof's method was also used here to determine the allowable bearing capacity for the fly ash-soil mixture.

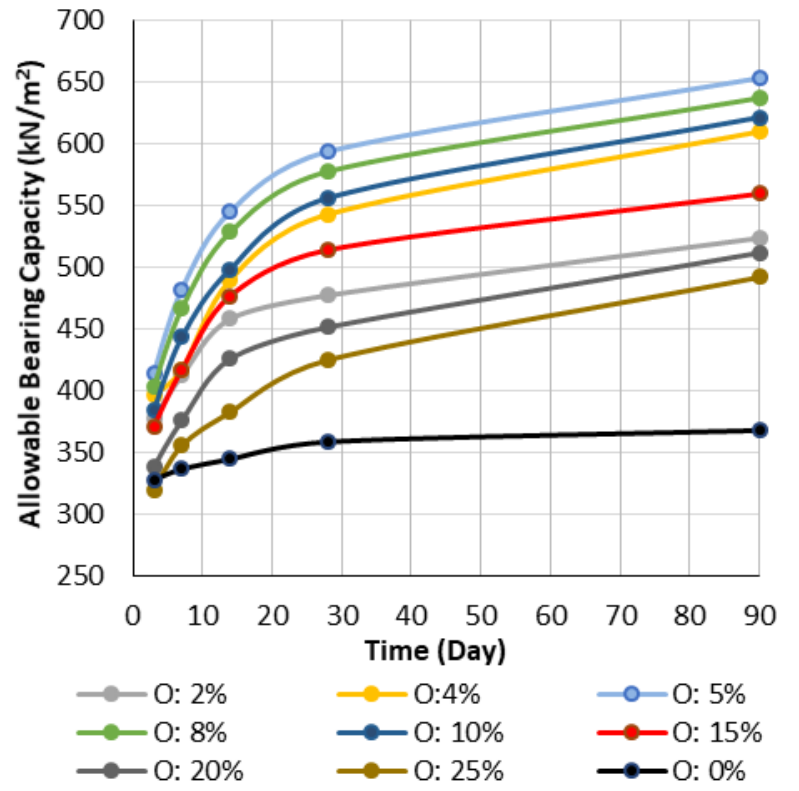

Fig. 7. Effect of allowable bearing capacity with Time for fly ash using Meyerhof method saturated state

("O" represents fly ash) 


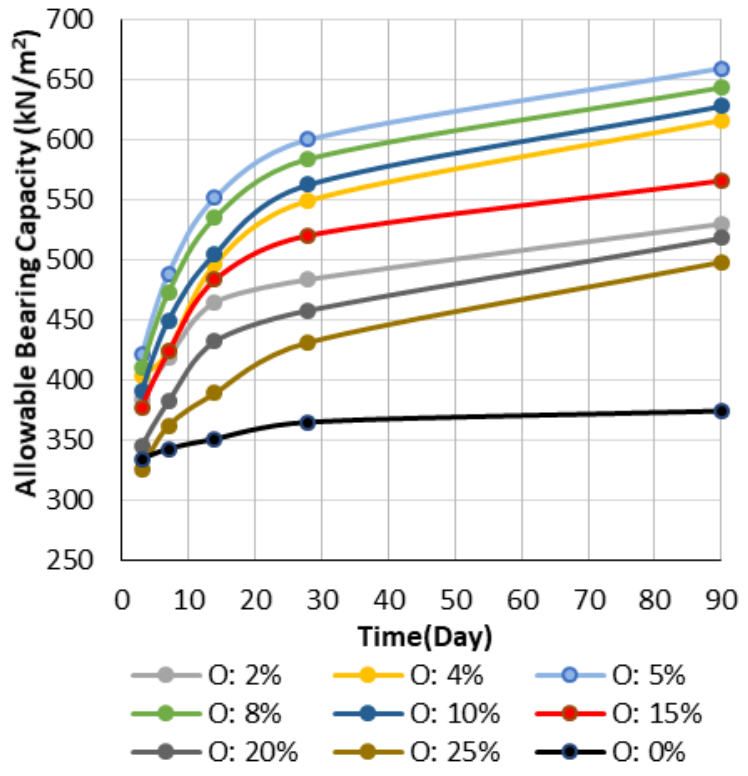

Fig. 8. Effect of allowable bearing capacity with Time for fly ash using Meyerhof method unsaturated state ("O" represents fly ash)

\section{Increment of Allowable Bearing Capacity with Time}

The increment of allowable bearing capacity was reported for time intervals of 3, 7, 14, 28 and 90 days using fly ash. The values of allowable bearing capacity were found using Terzaghi (1943), Meyerhof (1963), Skempton (1951), Hansen (1970) and Vesic (1973) methods. Values obtained from Meyerhof (1963) method were maximum in all the cases.

In the case of saturated fly ash-soil mix, the maximum increment of allowable bearing capacity was found at 90 days interval. Fig. 9 shows the increment of allowable bearing capacity for different time intervals for 5\% fly ash content. In the saturated condition, the maximum increment was found $77.74 \%$ for Meyerhof (1963) method.

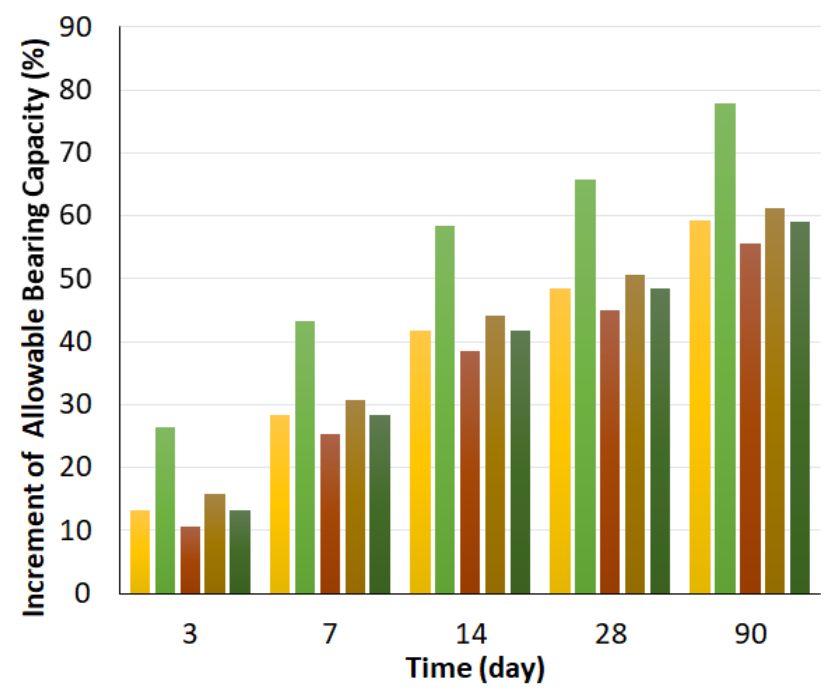

$\square$ Terzaghi $\square$ Meyerhof $\square$ Hansen $\square$ Vesic $\square$ Skempton

Fig. 9. Increment of allowable bearing capacity with time for 5\% fly ash (saturated)
The maximum increment of allowable bearing capacity for unsaturated condition was also found at 90 days interval. Fig. 10 shows the increment of allowable bearing capacity for different time intervals for $5 \%$ fly ash content. In the unsaturated condition, the maximum increment was found $60.69 \%$ by using Meyerhof (1963) method.

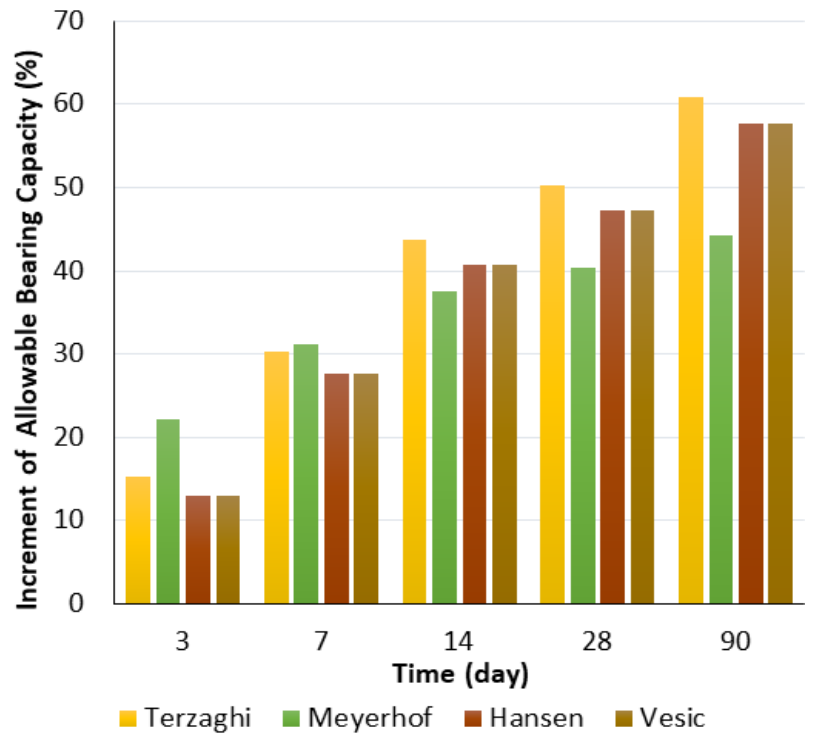

Fig. 10. Increment of allowable bearing capacity with time for $5 \%$ fly ash (unsaturated)

\section{E. Effect of Fly Ash Content on Void Ratio}

In this study, void ratio of the soil was measured before and after mixing fly ash with the soil.

The value of void ratio was found to increase with the increment of fly ash content.

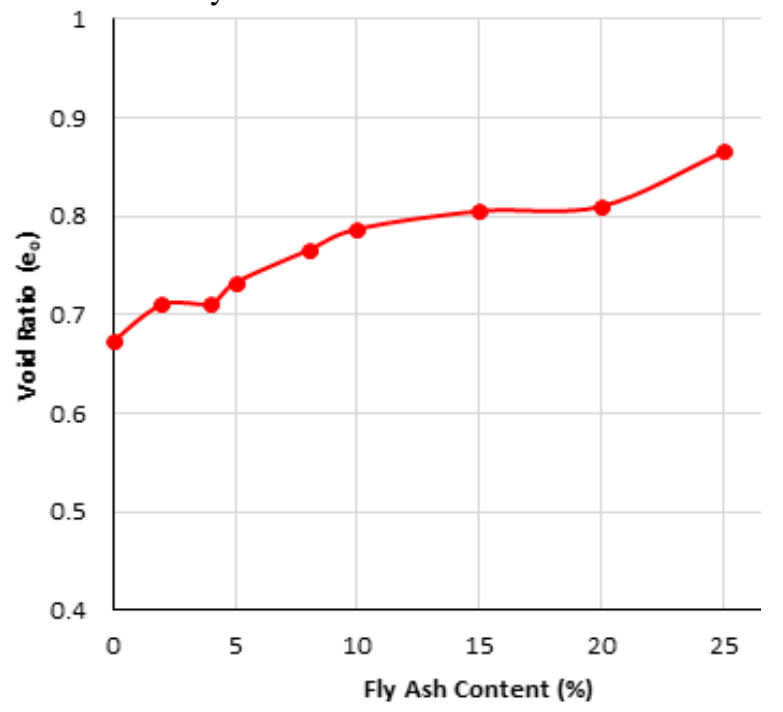

Fig. 11. Effect of fly ash content on void ratio

The test was conducted using $0 \%, 2 \%, 4 \%, 5 \%, 8 \%, 10 \%$, $15 \%, 20 \%$ and $25 \%$ fly ash contents. From Fig. 11, it can be seen that the maximum void ratio was found for $25 \%$ fly ash content $(0.865)$. The lowest void ratio was found 0.672 for normal soil. 


\section{F. Effect of Fly Ash Content on Settlement}

In this study, the secondary settlement was assumed as very small and it was neglected. The immediate settlement was also calculated and aggregated with the consolidation settlement, which is referred to as the total settlement. In the study, it was found that the value of the total settlement decreases as the fly ash content increases. The immediate settlement was $16 \mathrm{~mm}$ for both saturated and unsaturated conditions.

For soil with fly ash content, the lowest values of settlement were found $0.3166 \mathrm{~m}(316 \mathrm{~mm})$ and $0.183 \mathrm{~m}(183 \mathrm{~mm})$ for saturated and unsaturated conditions, respectively. Both of these values were obtained for $25 \%$ fly ash content (Fig. 12).

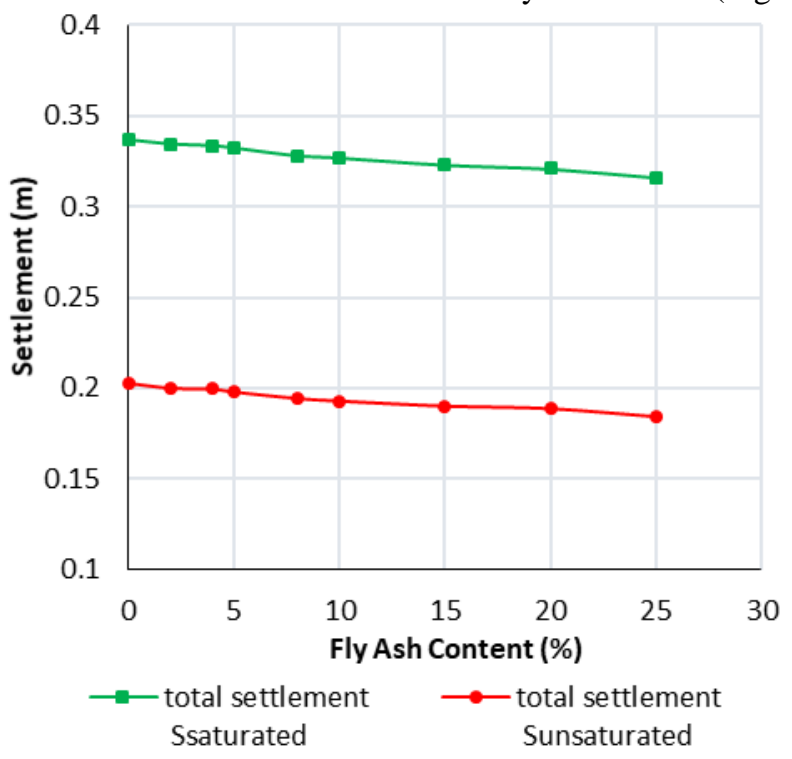

Fig. 12. Effect of fly ash content on settlement

Soil without the presence of fly ash experienced the highest total settlement, which were $0.336 \mathrm{~m}(336 \mathrm{~mm})$ and $0.203 \mathrm{~m}$ $(203 \mathrm{~mm})$ for saturated and unsaturated soil, respectively.

\section{G. Effect of Fly Ash Content on Degree of Consolidation}

After performing the degree of consolidation test, it was found that the degree of consolidation decreased with the increase in fly ash content. For $25 \%$ fly ash content, the least degree of consolidation values were achieved in both saturated and unsaturated condition, which were respectively $92.09 \%$ and $86.39 \%$ (Fig. 13).

In each of the two conditions (e.g., fly ash \& saturated, fly ash $\&$ unsaturated), the highest degree of consolidation values were achieved for $0 \%$ fly ash content (Fig. 13).

\section{H. Effect of Fly Ash Content on Time for Consolidation}

Fig. 14 shows that the time required for consolidation is decreasing as the fly ash content is increasing.

For fly ash- soil mix, the least time required for consolidation were found 4.16 years and 3.19 years respectively for saturated and unsaturated condition (Fig. 14). These least durations were achieved for $25 \%$ fly ash content in both the cases.
In each of the two conditions (e.g., fly ash \& saturated, fly ash \& unsaturated), soil with $0 \%$ fly ash content required the highest time for consolidation (Fig. 14).

From all the above tests, the findings are summarized here. Using Meyerhof's method, the maximum allowable bearing capacity was achieved for $5 \%$ fly ash content. As the time duration increased, the allowable bearing capacity also increased. From settlement analysis, it was observed that the settlement decreases with the increase in fly ash content in soil-fly ash mix. The void ratio also increased with the increase in fly ash content in soil-fly ash mix. Both the degree of consolidation and time required for consolidation decreased with the increase in fly ash content in the soil-fly ash mix.

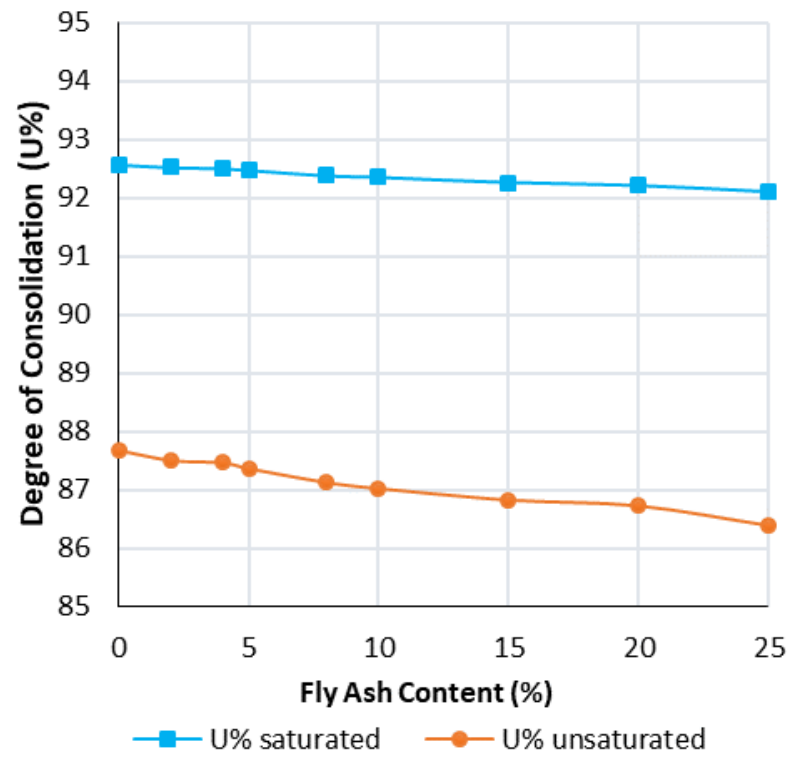

Fig. 13. Effect of fly ash content on degree of consolidation

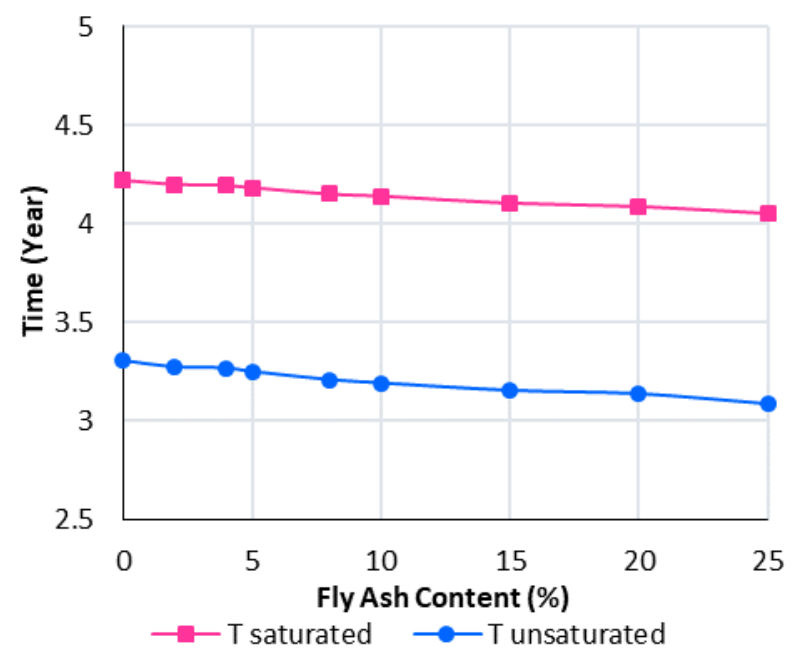

Fig. 14. Effect of fly ash content on time for consolidation

\section{CONCLUSION}

In this study, several laboratory UCS tests have been conducted for evaluating the improvement of the allowable bearing capacity of the collected soil sample from the paddy field. Besides these, the Atterberg limits are also evaluated for 
the settlement calculation of the same soil. After evaluation of the settlement, the degree of consolidation is also calculated, along with the time required for the desired degree of consolidation. All the engineering properties are evaluated here by performing a parametric analysis for a shallow foundation. From the analysis, it has been found that for 5\% fly ash content, the maximum allowable bearing capacity is achieved. Here, for determination of allowable bearing capacity, Terzaghi, Meyerhof, Skempton, Hansen, Vesic methods have been used and it is noted that from the Meyerhof method, the allowable bearing capacity demonstrates the highest value. The change of bearing capacity is observed for duration of 90 days and it is found that the bearing capacity increases with time. Besides these, the settlement and void ratio analysis have also been conducted and it has been found that for an increase in fly ash content, the total settlement decreases, while void ratio increases with the increment of fly ash content. From the analysis, it is also established that both the time requirement for the consolidation and the degree of consolidation decreases as the fly ash content increases.

Finally, it can be concluded that fly ash can be useful for the development of the bearing capacity of the soil and reducing settlement. Considering fly ash is a byproduct of power plants along with the fact that unplanned disposal of it can lead to serious environmental pollution, the use of fly ash in the development of the engineering properties of soil can certainly reduce the environment pollution. Therefore, it is recommended for convenient construction materials in the foundation, road construction, etc. As the compaction test cannot be done for soil having moisture content less than $20 \%$, study on a fully remolded soil sample for a high range of moisture content can also be considered. The interval between the percentages of fly ash content should be reduced in future studies. For example, the obtained results will be more precise if the difference of fly ash contents can be reduced to $1 \%$ or $0.5 \%$. Moreover, the effectiveness of other types of stabilizers such as polymers may also be investigated.

\section{REFERENCES}

[1] ASTM D854-04, Standard Test Methods for Specific Gravity of Soil Solids by Water Pycnometer, ASTM International, West Conshohocken, PA, 2004, DOI: 10.1520/D0854-04, www.astm.org

[2] ASTM D2216-04, Standard Test Methods for Laboratory Determination of Water (Moisture) Content of Soil and Rock by Mass, ASTM International, West Conshohocken, PA, 2004, DOI: 10.1520/D2166-04, www.astm.org

[3] ASTM D422-04, Standard Test Method for ParticleSize Analysis of Soils, ASTM International, West Conshohocken, PA, 2004, DOI: 10.1520/D0422-04, www.astm.org

[4] ASTM D4318-04, Standard Test Methods for Liquid Limit, Plastic Limit, and Plasticity Index of Soils,
ASTM International, West Conshohocken, PA, 2004, DOI: 10.1520/D4318-04, www.astm.org

[5] ASTM D1557-04, Standard Test Methods for Laboratory Compaction Characteristics of Soil Using Modified Effort (56,000 ft-lbf/ft3 (2,700 kN-m/m3)), ASTM International, West Conshohocken, PA, 2004 DOI: 10.1520/D1557-04, www.astm.org

[6] Chu SC, Kao HS. A study of engineering properties of a clay modified by fly ash and slag. In: SharpKD, editor. Fly ash for soil improvement-geotechnical special publication. New York: ASCE; 1993. p. 8999.

[7] Dermatas D, Meng X. Utilization of fly ash for stabilization/solidification of heavy metal contaminated soils. Eng Geol 2003;70:377-94.

[8] Hansen, J. B. A. Revised and Extended Formula for Bearing Capacity. Danish Geotechnical Institute, Copenhagen, 1973. Bulletin no 28

[9] Haque, M.E. (2013). Indian fly-ash: production and consumption scenario. International Journal of Waste Resources (IJWR) 3, no 1 (2013): 22-25. DOI: 10.12777/ijwr.3.1.2013: 22-25.

[10] Horpibulsuk S., R. Rachan, A. Chinkulkijniwat, Y. Raksachon, A. Suddeepong. "Analysis of strength development in cement-stabilized silty clay based on microstructural considerations." Construction and Building Materials 24, no 1 (2010): 2011-2021.

[11] Horpibulsuk S., Phetchuay C., and Chinkulkijniwat A., "Soil stabilization by calcium carbide residue and fly ash," Journal of Materials in Civil Engineering, vol. 24, no. 2, pp. 184-193, 2012.

[12] Inan G, Sezer A. A review on soil stabilization techniques and materials used. MBGAK proceedings. 2003. p. 369-377. [in Turkish].

[13] Keshawarz M. S. and Dutta U., "Stabilization of south Texas soils with fly ash," in Fly Ash for Soil Improvement, ASCE Geotechnical Special Publication no. 36, 1993.

[14] Kumar B.R.P., Sharma R.S., "Effect of fly ash on engineering properties of expansive soils," J. Geotech. Geoenviron. Eng. ASCE 130(7):764-767, 2004.

[15]Meyerhof, G.G. "Some recent research on the bearing capacity of foundations." Canadian Geotechnical Journal 1, no. 1 (1963): 16-26.

[16] Ngoma, I. and M.L Chirwa. "Laboratory Evaluation of Fly Ash and Lime for Stabilizing Clayey Soil on Low Volume Unpaved Roads." Paper presented at 5th Africa Transportation Technology Transfer (T2) Conference, Tanzania, Naura Springs Hotel in Arusha, 21 November 2011 - 25 November 2011.

[17] Prabakar J., Dendorkar N., and Morchhale R. K., "Influence of fly ash on strength behavior of typical soils," Construction and Building Materials, vol. 18, no. 4, pp. 263-267, 2004

[18] Savran KZ. Stabilization of cohesive soils with fly ash. Ankara: METU; 1988.

[19] Şenol, A., Bin-Shafique, M., Edil, T., \& Benson, C. Use of Class C Fly Ash for the Stabilization of Soft 
Subgrade. ARI, The Bulletin of the İstanbul Technical University, 53, pp. 89-95.2003.

[20] Senol A, Bin-Shafique MdS, Edil TB, Benson CH. Use of class $\mathrm{C}$ fly ash for stabilization of soft subgrade. ACE proceedings 2002. p. 963-72.

[21] Şenol, A., Edil, T., Bin-Shafique, M. S., Acosta, H., \& Benson, C. H. Soft Subgrades' Stabilization by Using Various Fly Ashes. Resources, Conservation and Recycling, 46(4), pp. 365-76. 2006.

[22] Sharma, N.K., S.K. Swain, and U.C. Sahoo. "Stabilization of a Clayey Soil with Fly Ash and Lime: A Micro Level Investigation." Geotechnical and Geological Engineering 24, No. 02 (2012)

[23] Skempton, A. W. "Notes on the Compressibility of Clays." Q. J. Geol. Soc. London 100, no 1-4 (1944): 119-135.

[24] Tastan E. O., Edil T. B., Benson C. H., and Aydilek A. H., "Stabilization of organic soils with fly ash," Journal of Geotechnical and Geoenvironmental Engineering, vol. 137, no. 9, pp. 819-833, 2011.

[25] Terzaghi, K., R. Peck, and G. Mesri. Soil Mechanics in Engineering Practice. 3rd ed. New York: John Wiley and Sons, 1996.

[26] Turner JP. Evaluation of western coal fly ashes for stabilization of low-volume roads. In: Wasemiller MA, Hoddinott B, editors. Testing soils mixed with waste or recycled materials. ASTM STP 1275; 1997. 340pp.

[27] Vesic, A. "Analysis of Ultimate Loads of Shallow Foundations." Journal of the Soil Mechanics and Foundations Division 99, no 1 (1973): 45-73.

[28]Zha, F., Liu, S., Du Y., and Cui, K. "Behavior of expansive soils stabilized with fly ash." Natural Hazards, 47 (3), 509-523. 2008.

Mr. Abul Hasnat received his Bachelor of Science degree

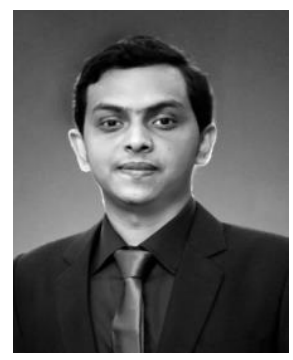

from Dept. of Civil and Environmental Engineering from Islamic University of Technology (IUT). He completed his Masters in Science in Structural Engineering from Bangladesh University of Engineering and Technology (BUET). Currently, he is working as Assistant Professor in Faculty of Engineering, American International University-Bangladesh (AIUB). He has several Local and International publications in the related field.
Safkat Tajwar Ahmed is currently working as a lecturer at

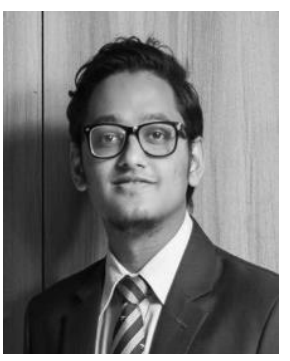
the Department of Civil Engineering of Sonargaon University (SU), Dhaka. His work focuses on the transportation engineering field, specifically traffic safety, comfort and other service quality attributes. Mr. Ahmed has published a number of conference papers and received awards in academic competitions. He completed his BSc in Civil Engineering from Islamic University of Technology (IUT) in 2017 and currently, he is planning to pursue higher studies abroad.

Tahmid Mustafa was born in Dhaka, Bangladesh in 1995. He

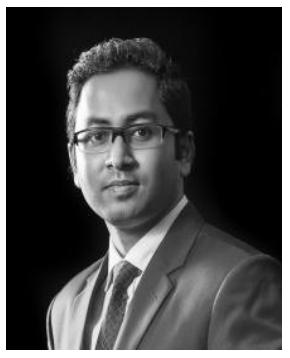
received the B.Sc. degree in Civil Engineering from Islamic University of Technology (IUT), Board Bazar, Gazipur, in 2017. He is an associate member of Institute of Engineers, Bangladesh (IEB). He joined Sonargaon University (SU) as a full-time faculty member on January of 2018. Since then, he kept himself associated over there with several research works, teaching his students and some vital departmental activities. His research interest includes utilizing waste materials within sub or super structure for reducing negative impacts on environment.

Md. Samiullah Chowdhury completed B.Sc in Civil and

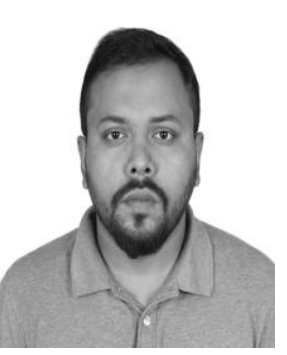
Environmental Engineering from Shahjalal University of Science and Technology in the year 2017. After that, he pursued his career at 'Prosoil Foundation Consultant' as a geotechnical engineer. Right now he is working at 'Padma Multipurpose Bridge Project' as a junior consultant engineer. His main research interests are geotechnical engineering and data science.

S.M.Prince received his B.Sc. Eng. Degree in Civil and

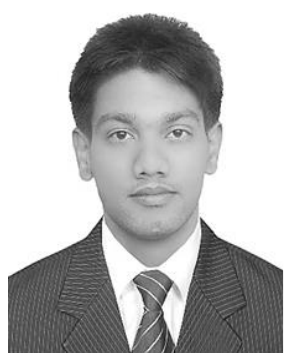
Environmental Engineering from Shahjalal University of Science and Technology (SUST), Sylhet in 2014. Currently he is pursuing his M.Sc. Degree in (WRD) Water Resources Development from Bangladesh University of Engineering and Technology (BUET), Bangladesh and working as a CSC (Construction Supervision Consultant) Engineer at FDEE (Frist Dhaka Elevated Expressway) Project in Dhaka. Mr S.M.Prince is an Associate member of IEB (Institute of Engineers Bangladesh).His research interests are geotechnical engineering, costal engineering, and water distribution system. 